\title{
Pityriasis lichenoid-like mycosis fungoides
}

\section{Fatima Azzahra El Gaitibi', Sara Oulad Ali', Jihane Belcadi', Kaoutar Znati², Mariame Meziane', Laila Benzekri' ${ }^{1}$, Nadia Ismaili' ${ }^{1}$, Karima Senouci'}

${ }^{1}$ Department of Dermatology, Mohammed V University in Rabat, Ibn Sina University Hospital, Rabat. Morocco, ${ }^{2}$ Department of Histopathology, Mohammed V University in Rabat, Ibn Sina University Hospital, Rabat. Morocco.

Corresponding author: Fatima Azzahra El Gaitibi, MD, E-mail: elgaitibi.fatimaazzahra@gmail.com

Sir,

Mycosis fungoides is a primary cutaneous T-cell lymphoma, secondary clonal proliferation of mature skin-homing T cells, mostly CD4-positive, with a predilection for involving the epidermis. It is an indolent lymphoma that progresses over several years and represents $50 \%$ of primary cutaneous T-cell lymphomas [1]. Its clinical presentation is variable, thus leading to several clinical variants. Herein, we describe a rare variant of mycosis fungoides: pityriasis lichenoid-like mycosis fungoides.

A 45-year-old female was referred to our department with a papular rash evolving for the last year without regression. The patient had a history of breast carcinoma in complete remission for two years. A clinical examination revealed erythematous, scaly, non-itchy papules covering the entire body but sparing the face (Figs. 1 and 2). There was no scalp involvement or associated lymphadenopathy. Based on the clinical presentation, the suggested diagnosis was pityriasis lichenoid. A histological examination revealed Pautrier's microabscesses, atypical lymphocyte infiltration along the basal layer and papillary dermis, and prominent epidermotropism (Fig. 3). There was pilotropism without mucin. Besides, hyperkeratosis with focal parakeratosis and perivascular infiltrate were noted. An immunohistochemical analysis revealed infiltrates of $\mathrm{T}$ cells expressing CD3, CD2, CD5, and a predominance of CD4-positive T cells in the epidermis compared to CD8-positive T cells. CD7 and CD30 were, however, negative. These findings were consistent with pityriasis lichenoid-like mycosis fungoides. The patient was classified as a IB stage and received UVB phototherapy with good progress.

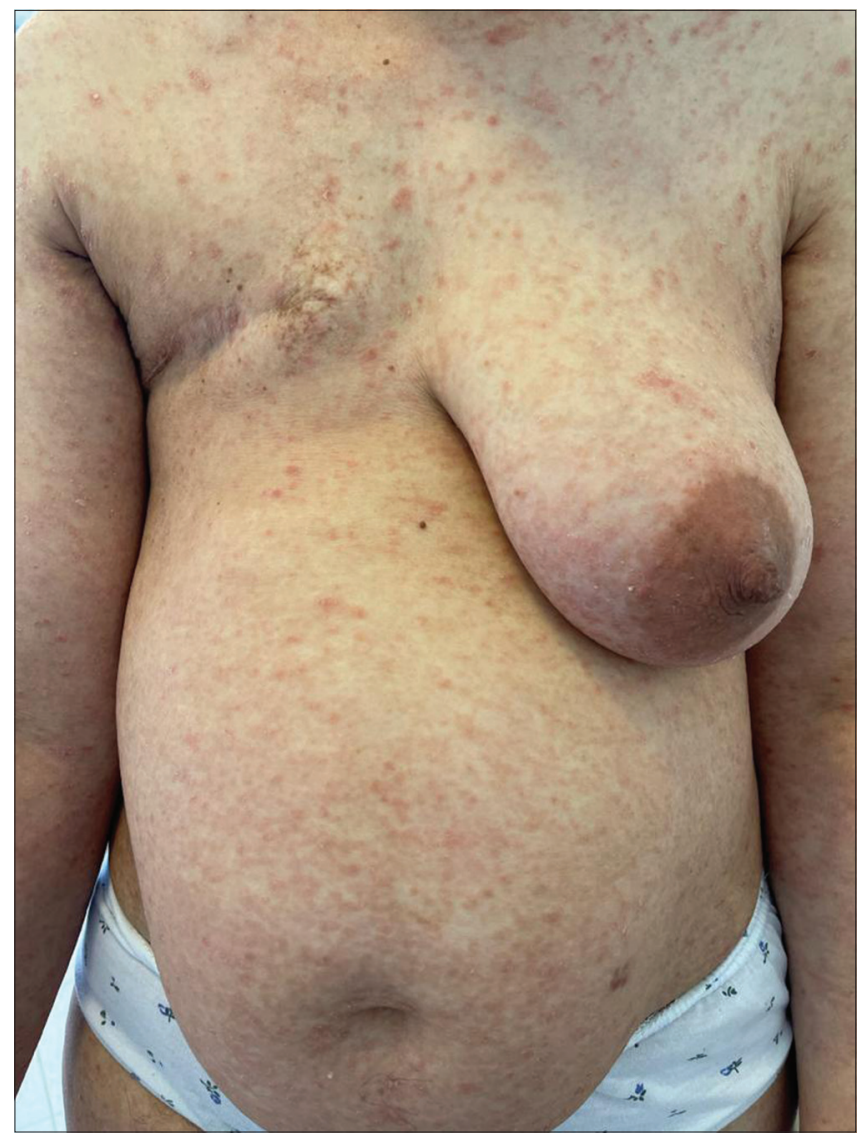

Figure 1: Generalized erythematous scaly papules on the trunk.

Pityriasis lichenoid-like mycosis fungoides, first described by Ko et al. [2], is a rare form of mycosis fungoides, with only several cases reported in the literature [3]. It differs from the classic form by the presence of erythematous or pigmented, scaly, and non-itchy papules that resemble pityriasis lichenoid, from which it differs by the absence of spontaneous regression of the lesions. Histologically, pityriasis

How to cite this article: El Gaitibi FZ, Ali SO, Belcadi J, Znati K, Meziane M, Benzekri L, Ismaili N, Senouci K. Pityriasis lichenoid-like mycosis fungoides. Our Dermatol Online. 2022;13(1):116-117.

Submission: 28.02.2021; Acceptance: 29.04.2021

DOI: 10.7241 /ourd.20221.33 


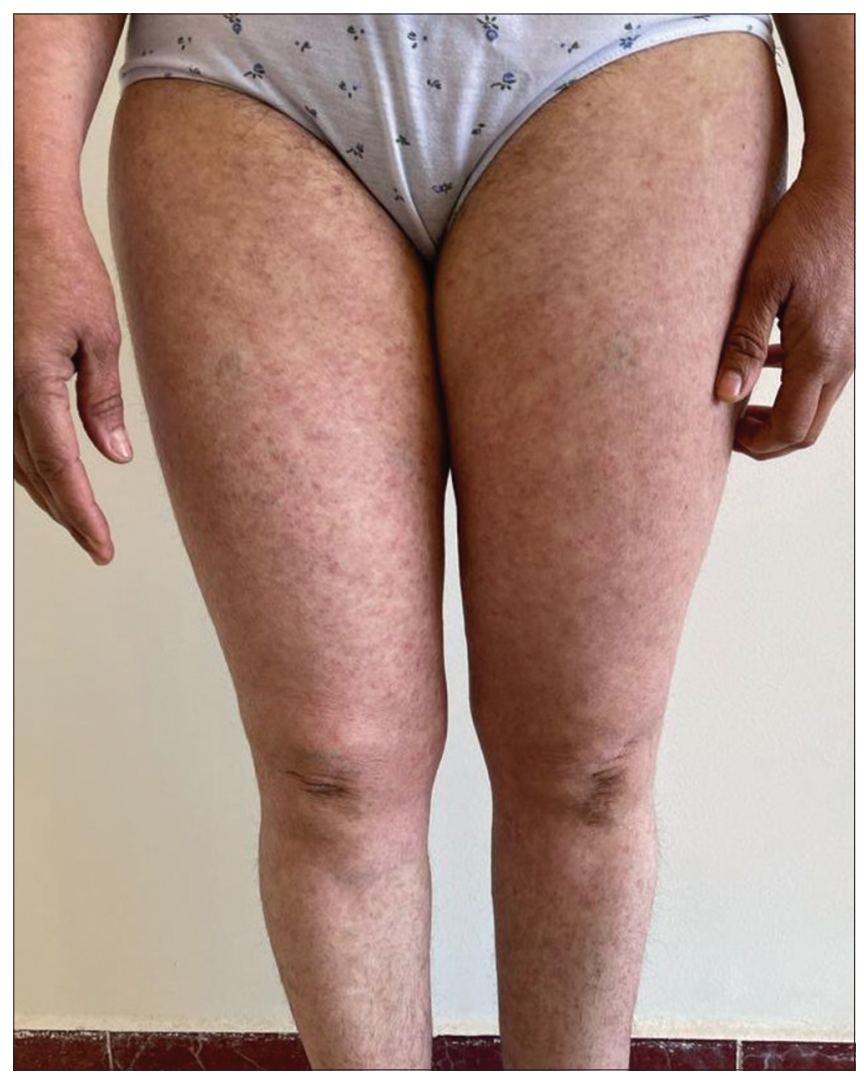

Figure 2: Generalized erythematous scaly papules on the lower extremities.

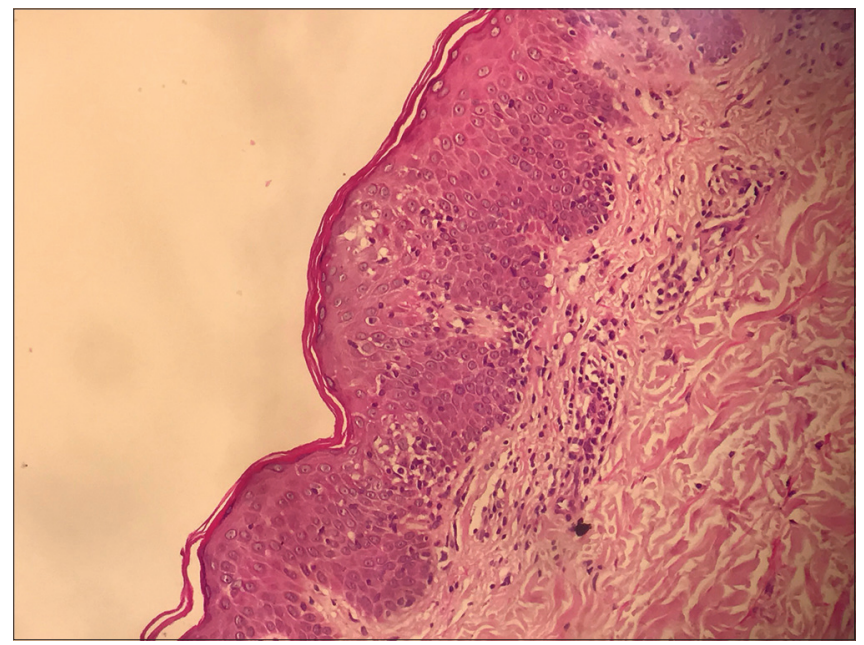

Figure 3: Biopsy specimens showing Pautrier's microabscesses, atypical lymphocyte infiltration along the basal layer, and prominent epidermotropism.

lichenoid-like mycosis fungoides is characterized by the association of features of mycosis fungoides (Pautrier's microabscesses, lymphocytes along basal cells, intraepidermal lymphocytes larger than dermal lymphocytes, haloed lymphocytes, stuffed lymphocytes in the dermal papilla, coarse collagen bundles in the papillary dermis) and those of pityriasis lichenoid (hyperkeratosis with focal parakeratosis, spongiosis, erythrocyte extravasation, exocytosis of lymphocytes and neutrophils, and, occasionally, the presence of apoptotic keratinocytes). Tumoral lymphocytes are more often CD $8+$ but may also express CD $4+$. In many cases, polyclonal CD3 $\mathrm{T}$ cells may also be present, and, in some instances, even small CD30+ lymphocytes may be detected $[4,5]$.

In the present case, the clinical presentation, the absence of spontaneous resolution, and the histopathological findings were consistent with the diagnosis of pityriasis lichenoid-like mycosis fungoides, which remains a challenging diagnosis.

\section{Consent}

The examination of the patient was conducted according to the principles of the Declaration of Helsinki.

The authors certify that they have obtained all appropriate patient consent forms, in which the patients gave their consent for images and other clinical information to be included in the journal. The patients understand that their names and initials will not be published and due effort will be made to conceal their identity, but that anonymity cannot be guaranteed.

\section{REFERENCES}

1. Willemze R, Jaffe ES, Burg G, Cerroni L, Berti E, Swerdlow SH, et al. WHO-EORTC classification for cutaneous lymphomas. Blood. 2005;105:3768-85.

2. Ko JW, Seong JY, Suh KS, Kim ST. Pityriasis lichenoides-like mycosis fungoides in children. Br J Dermatol. 2000;142:347-52.

3. Hodak E, Amitay-Laish I. Mycosis fungoides: A great imitator. Clin Dermatol. 2019;37:255-67.

4. Jang MS, Kang DY, Park JB, Kim JH, Park KA, Rim H, et al. Pityriasis lichenoides-like mycosis fungoides: Clinical and histologic features and response to phototherapy. Ann Dermatol. 2016;28:540-7.

5. de Unamuno Bustos B, Ferriols AP, Sánchez RB, Rabasco AG, Vela CG, Piris MA, et al. Adult pityriasis lichenoides-like mycosis fungoides: A clinical variant of mycosis fungoides. Int J Dermatol. 2014:53:1331-8.

Copyright by Fatima Azzahra El Gaitibi, et al. This is an open access article distributed under the terms of the Creative Commons Attribution License, which permits unrestricted use, distribution, and reproduction in any medium, provided the original author and source are credited.

Source of Support: Nil, Conflict of Interest: None declared. 